\title{
Gas Permeability and Production Potential of Marine Hydrate Deposits in South China Sea
}

\author{
Pengfei Shen ${ }^{1,2,3}{ }^{-}$, Gang $\mathrm{Li}^{3}$, Jiangfeng Liu ${ }^{4}$, Xiaosen $\mathrm{Li}^{1,2,3, *}$ and Jinming Zhang ${ }^{3}$ \\ 1 State Key Laboratory of Coal Mine Disaster Dynamics and Control, Chongqing University, \\ Chongqing 400044, China; shenpf@ms.giec.ac.cn \\ 2 School of Resources and Safety Engineering, Chongqing University, Chongqing 400044, China \\ 3 Key Laboratory of Gas Hydrate, Guangzhou Institute of Energy Conversion, Chinese Academy of Sciences, \\ Guangzhou 510640, China; ligang@ms.giec.ac.cn (G.L.); j.zhang@hzdr.de (J.Z.) \\ 4 State Key Laboratory for GeoMechanics and Deep Underground Engineering, China University of Mining \\ and Technology, Xuzhou 221116, China; jeafliu@hotmail.com \\ * Correspondence: lixs@ms.giec.ac.cn; Tel.: +86-020-8705-2746
}

Received: 30 September 2019; Accepted: 24 October 2019; Published: 28 October 2019

\begin{abstract}
The permeability of marine sediments is critical to the gas production assessment of hydrate reservoirs. In this work, the sample of natural marine sediments was obtained from Shenhu Area of South China Sea at the depth of $1600 \mathrm{~m}$, and the gas permeability of the sample was measured in the laboratory under various confining pressures. The porosity of the sample decreased from $41.82 \%$ to $29.54 \%$, and the effective gas permeability of the sample decreased from $2.638 \times 10^{-16} \mathrm{~m}^{2}$ to $0.872 \times 10^{-16} \mathrm{~m}^{2}$ as the confining pressure increased from 0 to $23 \mathrm{MPa}$. The gas permeability of the natural sediments was determined to be $1.535 \times 10^{-16} \mathrm{~m}^{2}$ with confining pressure of $15 \mathrm{MPa}$ and porosity of $32 \%$. The deformation of sample in longitudinal direction was sensitive to the confining pressure, and the compressibility in the radial direction was limited. On the basis of the experimental results, the particle size term in the classical Kozeny-Carman equation was revised by correction factor $\mathrm{N}$, and the experimental results fitted well with the curves with $\mathrm{N}=2.40$. Moreover, the gas production potential at the site of $\mathrm{W}-17$ in the Shenhu Area was numerically studied based on the measured gas permeability. The simulation results showed that the cumulative volume of produced gas was approximately $1.46 \times 10^{6} \mathrm{ST} \mathrm{m}^{3}$ after 30 years. A new enlarged permeable well wall method was proposed to improve the poor gas production caused by low permeability. The cumulative gas production increased by 2.7 times as the permeable well wall radius increased from 0 to $5 \mathrm{~m}$. Regarding the gas and water production rates, water production increased with the increase of permeable well wall radius. Spatial distributions of hydrate and gas saturations, pressure, and temperature were investigated as well.
\end{abstract}

Keywords: gas permeability; natural sediments; gas hydrate; enlarged permeable well wall; South China Sea

\section{Introduction}

Natural gas hydrates (NGHs) are solid crystalline compounds composed of water and gas molecules, and the gas molecules are encaged inside the lattices of water cavities [1]. NGHs in nature are mainly concentrated in the deep ocean sediments and permafrost, where the necessary high pressures and low temperatures exist [2]. NGH have attracted global attentions because of its huge reserves and wide distributions, and NGH is considered as one of the most promising alternative energy sources in the 21st century [3,4]. In addition, the gas production from NGH deposits is considered to have a far higher impact on global economy than the impact of other unconventional natural 
gas [5]. However, the uncertainties, challenges, and issues facing gas production are still an inevitable problem [6]. There are four prevalent methods and techniques in dissociating methane hydrate from hydrate deposits: Depressurization [7-9], thermal stimulation [10-12], chemical inhibition [13-15], and $\mathrm{CO}_{2}$ replacement [16-18]. Combinations of these methods can also be employed, for example the huff and puff method, also known as cyclic steam stimulation, was used by Li et al. to evaluate the gas production of methane hydrate in porous media $[10,19]$. The heat-assisted antigravity drainage method was proposed to study the gas production potential from the Qilian Mountain permafrost hydrate deposits in the two horizontal wells [20]. However, all of these methods by means of depressurization combined with thermal stimulation are very inefficient in the deposits with very low permeability $(<1 \mathrm{mD})$ [21,22]. Therefore, a new method of increasing the permeability of hydrate sediments is urgently needed to improve the gas production efficiency.

The permeability characteristics of gas hydrate reservoirs are the decisive factors for gas production. Accurate quantification of gas effective permeability is very important in several engineering problems [23,24], including gas storage and production, drying and wetting processes, oil production, etc. Current experimental studies are mainly focused on artificial sediments with relatively high permeability [25]. The numerical simulations of hydrate production are also based on permeability higher than $75 \mathrm{mD}$ [22]. For example, Minagawa et al. measured the water permeability of the artificial methane hydrate sediments, and the reduction factor $\mathrm{N}$ values were obtained for the porous media of Toyoura sand, JIS No.7 sand, JIS No.7 sand, and Mallik simulated sand, respectively [26]. Masuda et al. proposed a complete empirical model, which provides a scheme for the prediction of relative permeability and hydrate saturation. This model has been widely used to verify the measurement results of different porous media [27]. There were few studies on low-permeability porous media such as natural cores and marine sediments, because it was difficult to obtain samples. In addition, the lack of measuring methods for very low-permeability cores or sediments was also a major reason. The effective permeability of natural sediment cores was measured to be $1-100 \mathrm{mD}$ in the Eastern Nankai Trough, and it was 2-3 orders of magnitude less than conventional estimates [28]. The mean permeability of the sediments in the South China Sea was measured to be 1.5-7.4 $\mathrm{mD}$ in the field when the mean effective porosity ranged from $32 \%$ to $35 \%$ [29]. So far, most of the research on the permeability of hydrate sediments is limited to the relationship between relative permeability and saturation, and no further application of the measured permeability has resulted in production experiments. Also, many numerical simulations are not based on permeability measurement results. Therefore, on the basis of measuring the permeability of sediments, evaluating the gas production of hydrate sediments will make the evaluation results more credible.

In this work, the natural sediments were obtained from the Shenhu Area of South China Sea at the depth of $1600 \mathrm{~m}$ below the sea level, and the sample number was ZSQD76. The sediments are non-diagenetic argillaceous silt reservoirs in natural state. Samples are comprised mainly of kaolinite, illite, and chlorite, with smectite a minor clay mineral [30]. In order to get closer to the real sediments in the seabed, the samples in this work are compacted under the confining pressure of $15 \mathrm{MPa}$, and the pressure of $15 \mathrm{MPa}$ is closer to the stress of the sediment in the original state. The state of the compressed sediments is shown in Figure 2. In the hydrate reservoir of Shenhu sea area, hydrate is considered to exist stably in the pores of the sediments [5]. When hydrate decomposes, the density of solid particles in the sediment will not change, but the density of hydrate deposits in the mining area will slightly decrease due to the limited sands production. We tried to use the deionized water to pass through the natural sediments samples with porosity of $30 \%$ at a constant pressure of 15 $\mathrm{MPa}$, and the experiment results proved that only very little deionized water was injected into the sample in $10 \mathrm{~h}$. There were two main reasons; the first was that the volume-weighted mean diameter of the sediments was only $6.491 \mu \mathrm{m}$, and the absolute permeability of the sediments was extremely low with porosity of $30 \%$. Second, the sediments contain smectite $(5 \%)$, illite $(31 \%)$, kaolinite $(46 \%)$, chlorite (18\%) [30]. The presence of smectite could strongly affect permeability when samples are saturated with water due to their swelling. Hence, for the porous media with very low permeability 
$(<1 \mathrm{mD})$, such as the natural sediments used in this study, gas may be the only media to go through the compacted sample because of its low diffusivity [31]. For the gas permeability measurements, the steady-state method was employed. The steady-state method was a steady injection state follows Darcy's law, and the pressure variation in the sample was given by the simplified gas flow formula as shown in Equation (1) [32,33].

Figure 1 shows the sketch map of northern South China Sea and the drilling expedition location of W-17 [34]. The drilling results showed that the NGH existed in silt clay formation, and it was difficult to exploit this kind of NGH because of its low-permeability characteristics [29]. The production test site was located in the middle of the southeastern continental slope of Shenhu area. The bottom of the hydrate bearing layer (HBL) was at the depth of $1572 \mathrm{~m}$, which was basically close to the depth of our obtained samples $(1600 \mathrm{~m})$. Since the position of the obtained sample sediments was close to the site of $\mathrm{W}-17$, it was believed that the geological environment of the sample sediments was more likely similar to the sediments at the site of $\mathrm{W}-17$. Hence, the gas production characteristics were numerically simulated based on the porosity, hydrate saturation, temperature, and pressure conditions of W-17 sediments. The measured gas permeability $\left(1.535 \times 10^{-16} \mathrm{~m}^{2}\right)$ of natural sediments with the confining pressure of $15 \mathrm{MPa}$ was used as the intrinsic permeability of the hydrate bearing layer. Considering that the improving of percolation capacity was the key to the production of low permeability reservoirs, an enlarged permeable well wall was used to promote the pressure propagation speed and distance. The enlarged permeable well wall filled with hydrophobic sand was surrounding the vertical production well in the production interval [35]. Hence, the production potential of hydrate deposits at site of $\mathrm{W}-17$ was evaluated based on the measured gas permeability of natural sediments.

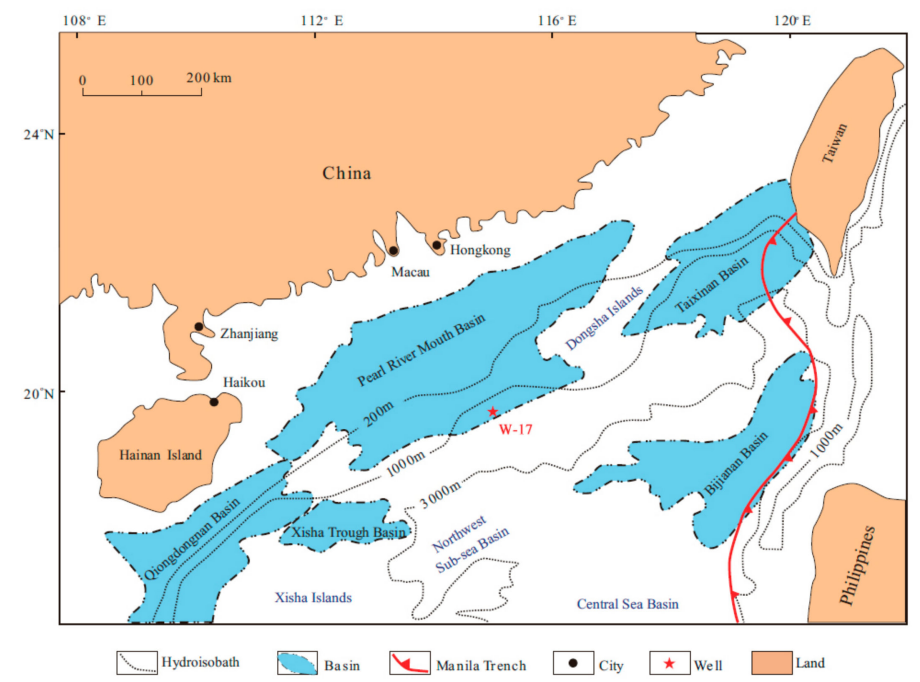

Figure 1. The location of W-17 in the South China Sea [34].

In this work, we aimed at evaluating the production potential of Shenhu Area of South China Sea based on the measured gas permeability of the natural marine sediments. First, the gas permeability of natural sediments was measured by the steady-state method under different confining pressures. After that, according to the porosity, hydrate saturation, temperature, and pressure conditions of $\mathrm{W}-17$, the gas production performance at the site of $\mathrm{W}-17$ was numerically studied based on the experimental results. Considering the low gas production of simulation results, we tried to adopt an enlarged permeable well wall to improve the pressure propagation speed and distance. The gas and water production and gas-to-water ratio were analyzed with different radii of enlarged permeable well wall. Spatial distributions of the characteristic parameters hydrate and gas saturations, pressure, and temperature were investigated as well. 


\section{Experiments}

\subsection{Apparatus}

As shown in Figure 2, the apparatus used for the gas permeability tests consists of a confining cell, a constant-pressure pump, a buffer vessel, and a newly developed interface to ensure airtightness, etc. The confining pressure $\left(\mathrm{P}_{\mathrm{C}}\right)$ is supplied by the constant-pressure pump, and its value is recorded on a computer through a digital pressure gauge. The buffer vessel with the inner volume of $400 \mathrm{~mL}$ made of $316 \mathrm{~L}$ stainless steel is used to provide a steady gas flow. The volume of buffer vessel is expressed by $\mathrm{V}_{0}$. The gas used for the gas permeability tests is pure argon (more than 99\%). Argon as an inert gas is considered to be an ideal gas to measure the gas permeability of the sediment, because its greater molecule mass could effectively decrease the magnitude of potential leaks. In the natural marine sediments used in this work, the adsorption of methane gas cannot be ignored, because the methane gas adsorbed in the sediments will reduce the flow rate. Therefore, argon gas is used instead of methane gas to determine the gas permeability of the sediments. Two high-precision manometers are installed at both sides of the buffer vessel. The inlet pressure labeled as $\mathrm{P}_{1}$ is recorded once per second during the gas permeability measurement. The outlet pressure labeled as $\mathrm{P}_{0}$ is set to be the atmospheric pressure. In addition, all tests are carried out in a constant temperature room at $293.15 \mathrm{~K}$.

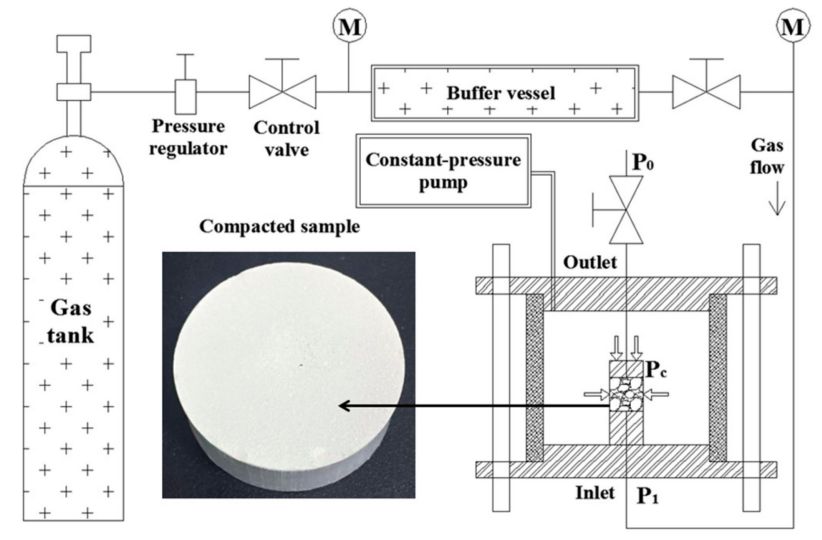

Figure 2. Experiment device used for gas permeability measurements.

\subsection{Materials and Sample Preparation}

In this study, the natural sediments used as the porous media were dried for $120 \mathrm{~h}$ at the temperature $393.15 \mathrm{~K}$ and then pulverized. The purpose of removing the moisture content from sediments is to prevent smectite in sediments from swelling with water. The solid density and volume-weighted mean diameter of the sample were $2.42 \mathrm{~g} / \mathrm{cm}^{3}$ and $6.491 \mu \mathrm{m}$, respectively. As shown in Figure 3, the particle size distributions and volume-weighted mean diameters measurement results of the natural sediments, which were measured using the Mastersizer 2000E produced by Malvern Instruments Ltd., United Kingdom. The particle size distributions of the sample were measured three times, and the three measurements were in good agreement. The sediments with volume-weighted mean diameter less than $1.0 \mu \mathrm{m}$ were approximately $10 \%$, and only very few sediments with the volume-weighted average diameter greater than $15.0 \mu \mathrm{m}$. Sample I and sample II with a mass of $46.95 \mathrm{~g}$ and $47.05 \mathrm{~g}$ were placed into the cylinder tank, respectively, and then installed the piston to preliminarily compact the sample. The axial pressure of the piston cylinder was $15 \mathrm{MPa}$ and the compression time was $2 \mathrm{~h}$. The resulting heights of sample I and sample II were $17.25 \mathrm{~mm}$ and $17.22 \mathrm{~mm}$, respectively. The resulting diameters of sample I and sample II were $49.61 \mathrm{~mm}$ and $49.80 \mathrm{~mm}$, respectively. Hence, the initial porosities of sample I and sample II were $41.82 \%$ and $42.04 \%$, respectively. 


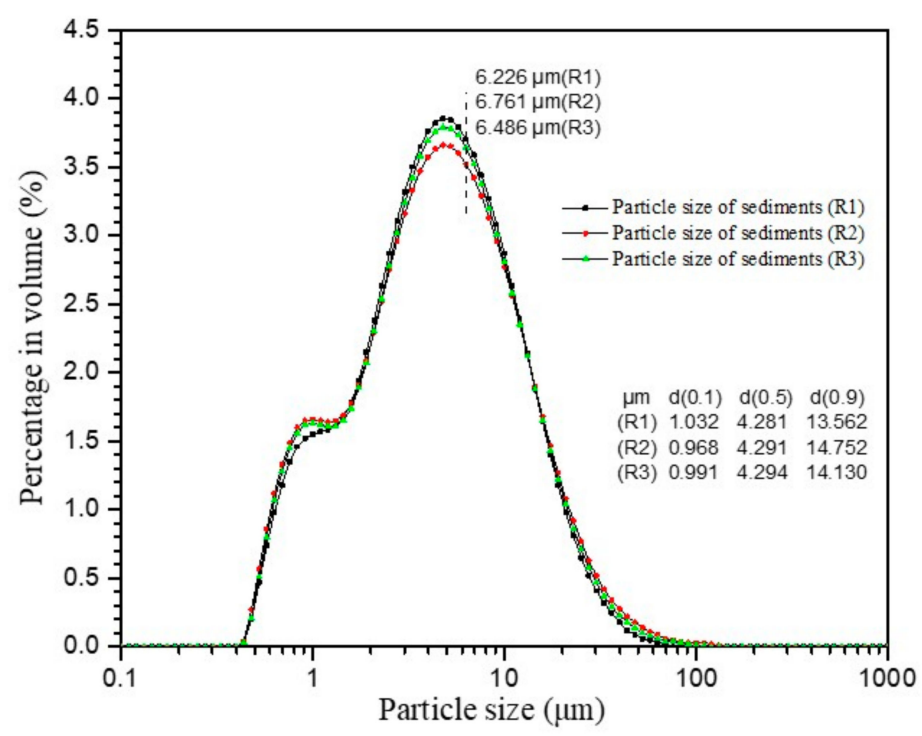

Figure 3. Particle size distributions of sediments in the South China Sea.

\subsection{Method to Measure Gas Permeability}

Darcy's law was employed to measure the gas permeability due to the continuous gas flow through the sample under steady conditions, and the effective gas permeability $K_{\text {eff }}$ could be applied as follows $[23,31,36]$ :

$$
K_{\mathrm{eff}}=\frac{\mu_{\mathrm{g}} Q_{\mathrm{g}}}{A} \frac{2 h P_{\mathrm{m}}}{\left(P_{\mathrm{m}}^{2}-P_{0}^{2}\right)}
$$

where $\mu_{\mathrm{g}}$ was the viscosity of argon $\left(2.2 \times 10^{-5} \mathrm{~Pa} \cdot \mathrm{s}\right), Q_{\mathrm{g}}$ was the average gas volume rate, $h$ was the length of sample, $A$ was the sample cross-section, and $P_{\mathrm{m}}$ was the average of upstream gas pressure at the inlet.

As shown in Figure 2, the inlet of the cylinder sample was subjected to a given pressure $P_{1}$. The outlet was subjected to constant atmospheric pressure of $P_{0}$. There was a pressure decrease $(\Delta P)$ after a period of time $(\Delta t)$ under the driving force of the pressure difference. By assuming a quasi-static flow and the ideal gas state equation [33], the average gas volume rate $\left(Q_{\mathrm{g}}\right)$ and the average of upstream gas pressure at the inlet $\left(P_{\mathrm{m}}\right)$ were calculated with the following equations, respectively:

$$
\begin{gathered}
Q_{\mathrm{g}}=\frac{V_{0} \Delta P}{P_{\mathrm{m}} \Delta t} \\
P_{\mathrm{m}}=P_{1}-\frac{\Delta P}{2} .
\end{gathered}
$$

Combining Equations (1)-(3), the effective gas permeability $K_{\text {eff }}$ could be expressed as follows:

$$
K_{\text {eff }}=\frac{\mu_{\mathrm{g}} V_{0} \Delta P}{A \Delta t} \frac{2 h}{\left(P_{1}-\frac{\Delta P}{2}\right)^{2}-P_{0}^{2}} .
$$

\subsection{The Effective Gas Permeability Results}

\subsubsection{The Relative Displacement}

The sample was placed in triaxial cell with confining pressure of $P_{\mathrm{C}}$. The confining pressure was gradually increased from 0 to $23 \mathrm{MPa}$, and the pressure points of experiments were $2 \mathrm{MPa}, 5 \mathrm{MPa}$, $8 \mathrm{MPa}, 10 \mathrm{MPa}, 15 \mathrm{MPa}, 20 \mathrm{MPa}$, and $23 \mathrm{MPa}$, respectively. Figure 4 shows the radial and longitudinal deformation of sample I and sample II as confining pressure increased from 0 to $23 \mathrm{MPa}$. At the end 
of the experiments, the radial deformations of sample I and sample II were $1.724 \mathrm{~mm}$ and $1.465 \mathrm{~mm}$, and the longitudinal deformations of sample I and sample II were $1.960 \mathrm{~mm}$ and $2.381 \mathrm{~mm}$. In other words, sample I was compressed by $3.48 \%$ in the radial direction and $11.37 \%$ in the longitudinal direction. Sample II was compressed by $2.94 \%$ in the radial direction and $13.83 \%$ in the longitudinal direction. Hence, the longitudinal deformation was very sensitive to the confining pressure, and the compressibility of sample in the radial direction was not obvious. The radial deformation curves of sample I and sample II were close to a straight line as confining pressure increased from $0 \mathrm{MPa}$ to $23 \mathrm{MPa}$. The longitudinal deformation was evident as the confining pressure increased from 0 to $2 \mathrm{MPa}$, and then decreased with the increase of confining pressure.

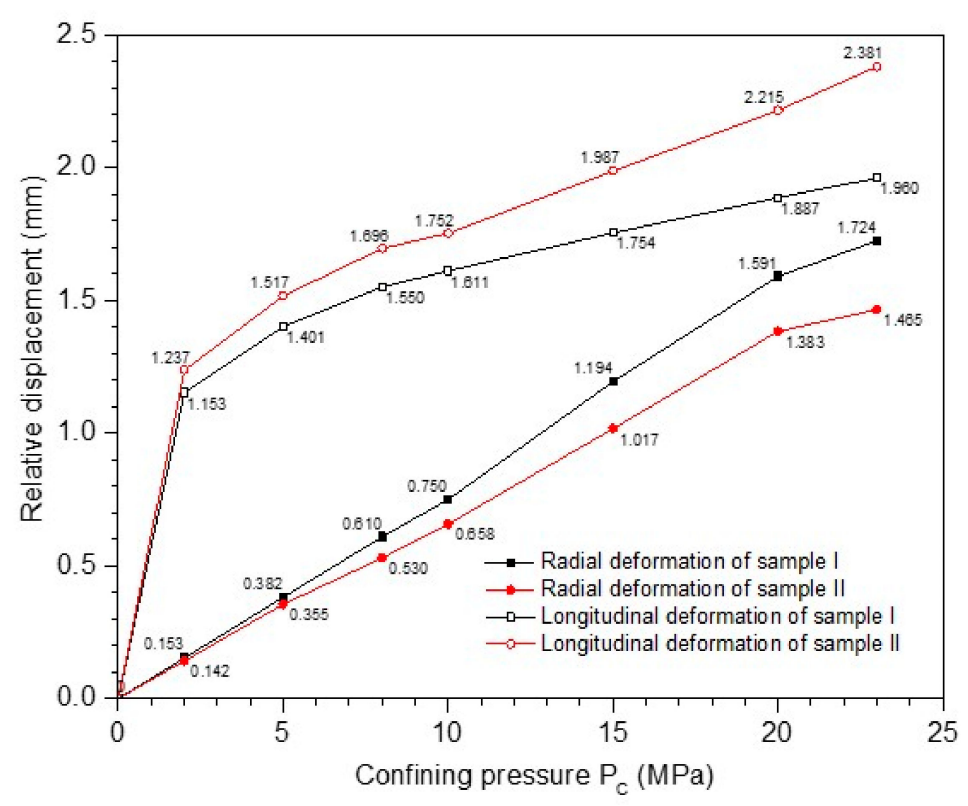

Figure 4. The radial and longitudinal deformation of samples I and II over confining pressure.

\subsubsection{The Variation of Inlet Pressure during the Experiment}

The measurement methods were similar under different confining pressure conditions, so only the determination of the measurement point at a confining pressure of $15 \mathrm{MPa}$ was given. Figure 5 shows the inlet pressure $\left(P_{1}\right)$ changes of sample I and sample II during gas permeability measurement with the confining pressure of $15 \mathrm{MPa}$. The whole measurement process could be divided into two stages. In stage I, also named preparation stage, the gas flow from the buffer vessel into the triaxial cell was in a stable state. In this preparation stage, it took a long time for the pressure to stabilize and remaining constant, and we only drew $35 \mathrm{~s}$ after stabilization. In stage II, the control valve was opened (point $\mathrm{A}$ and $\mathrm{D}$ ), and there was a pressure decrease $(\Delta P)$ of inlet pressure $\left(P_{1}\right)$ after a period of time $(\Delta t)$ under the driving force of the pressure difference. Namely, the outlet pressure $\left(P_{0}\right)$ of the triaxial cell was set to be atmospheric pressure. In other words, with the increase of time from $35 \mathrm{~s}$ to $120 \mathrm{~s}$, the inlet pressure $\left(P_{1}\right)$ of sample I decreased from $2.04 \mathrm{MPa}$ (point $\left.\mathrm{D}\right)$ to $1.75 \mathrm{MPa}$ (point $\mathrm{F}$ ), and the inlet pressure $\left(P_{1}\right)$ of sample II decreased from $2.17 \mathrm{MPa}$ (point A) to $1.86 \mathrm{MPa}$ (point C). That was to say, the inlet pressure of sample I and sample II decreased by $0.29 \mathrm{MPa}$ and $0.31 \mathrm{MPa}$ in $85 \mathrm{~s}$, respectively. The $\Delta P / \Delta t$ ratio of two samples was very close. Hence, the gas permeability results measured at the point $\mathrm{B}$ and $\mathrm{E}$ were determined to be the value of the effective gas permeability with the confining pressure of $15 \mathrm{MPa}$. The same method was applied in other confining pressure measuring points. 


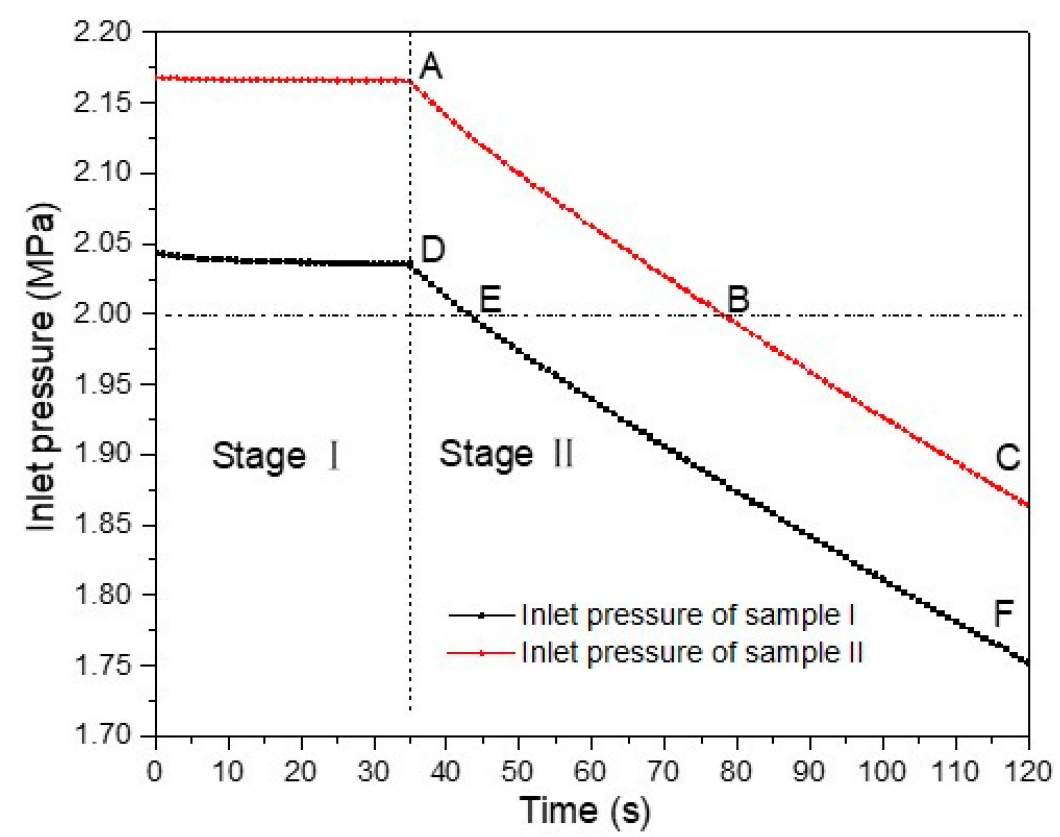

Figure 5. The inlet pressure changes during gas permeability measurement $\left(P_{C}=15 \mathrm{MPa}\right)$.

\subsubsection{The Effective Gas Permeability and Corresponding Porosity Changes}

Figure 6 shows the effective gas permeability and corresponding porosity change results. The two sets of measurement results were consistent. The experimental results showed that the gas permeability and the porosity were very sensitive to the confining pressure. The experimental results could be divided into three stages. In stage I, the gas permeability of the samples decreased rapidly as the confining pressure increased from $2 \mathrm{MPa}$ to $5 \mathrm{MPa}$, which was due to the compression of the sample. In stage II, the gas permeability of both samples gradually slowed down as the confining pressure increased from $5 \mathrm{MPa}$ to $15 \mathrm{MPa}$; namely, the gas flow through the sample was more uniform and stable than that in the stage I. In stage III, with the confining pressure increased from $15 \mathrm{MPa}$ to $23 \mathrm{MPa}$, the rate of gas permeability reduction was obviously higher than that of the stage II, because the samples structure changed, and the sample was more compact. With the confining pressure increased from $0 \mathrm{MPa}$ to $23 \mathrm{MPa}$, the porosity of sample I decreased from $41.82 \%$ to $29.54 \%$ and the porosity of sample II decreased from $42.04 \%$ to $28.60 \%$, respectively. Also, the effective gas permeability of the sample I decreased from $2.638 \times 10^{-16} \mathrm{~m}^{2}$ to $0.872 \times 10^{-16} \mathrm{~m}^{2}$ and the effective gas permeability of the sample II decreased from $2.642 \times 10^{-16} \mathrm{~m}^{2}$ to $0.841 \times 10^{-16} \mathrm{~m}^{2}$ as the confining pressure increased from $2 \mathrm{MPa}$ to $23 \mathrm{MPa}$. Taking the measurement point of $15 \mathrm{MPa}$ confining pressure as an example, the effective gas permeability of sample I and sample II were $1.535 \times 10^{-16} \mathrm{~m}^{2}$ and $1.505 \times 10^{-16} \mathrm{~m}^{2}$ and the porosity of sample I and sample II were $32.00 \%$ and $31.71 \%$, respectively. 


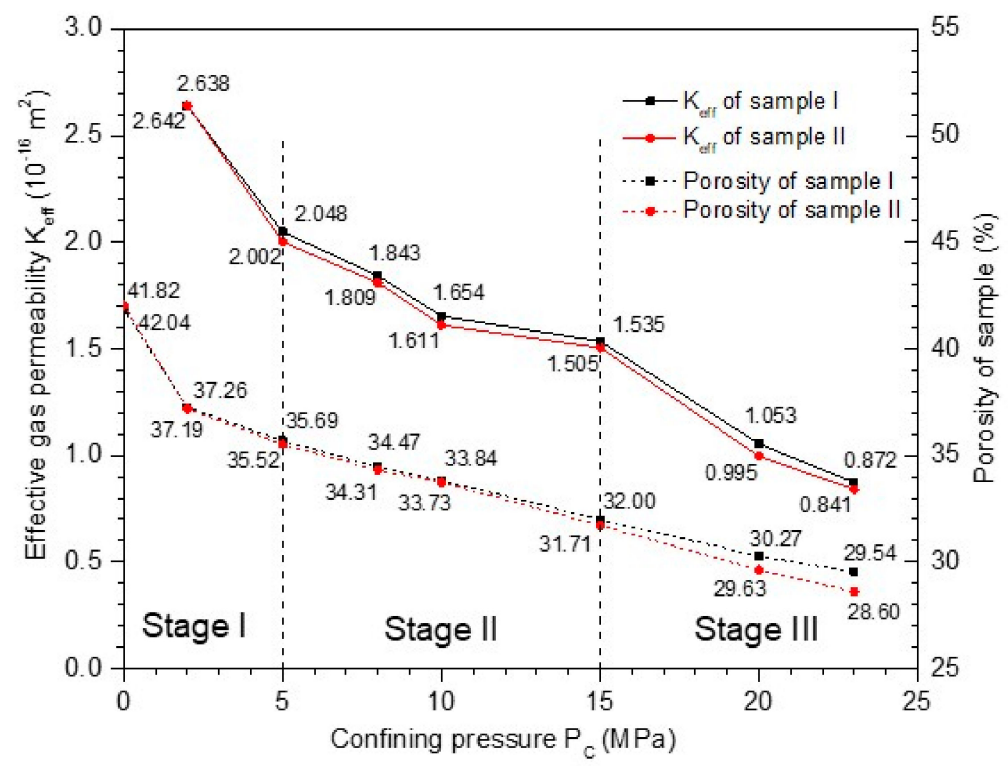

Figure 6. The effective gas permeability results and corresponding porosity changes.

\subsubsection{The Revision of Kozeny-Carman Equation}

The classical Kozeny-Carman (KC) equation of the permeability-porosity relationship was applied to groundwater flow, chemical engineering, and other fields. The KC equation could be simplified as the following formula [37-39]:

$$
K_{0}=\frac{\phi^{3}}{36 k(1-\phi)^{2}} D^{2}=\frac{\phi^{3}}{180(1-\phi)^{2}} D^{2}
$$

where $k$ was the $\mathrm{KC}$ constant, and we employed $k=5$ as the empirical $\mathrm{KC}$ constant in this work; $\phi$ was the porosity of the sample and $D$ was the mean diameter of the sediments $(D=6.491 \mu \mathrm{m})$.

The surface of particles in sediment was not smooth, and the particles were not spherical. Hence, the particle size term in the KC formula was revised by a correction factor $(\mathrm{N})$ in this paper. The revised formula was expressed as follows:

$$
K_{0}=\frac{D^{N}}{180} \frac{\phi^{3}}{(1-\phi)^{2}}
$$

Figure 7 shows the relationship between the effective gas permeability and the porosity of the samples. The mean diameter $(D=6.491 \mu \mathrm{m})$ was used as the volume-weighted mean diameter of the sediments. Three kinds of $\mathrm{N}$ values were used to verify the experimental results. It fitted well with the experimental results when $\mathrm{N}$ value was 2.40. Furthermore, all the experimental results suited at the curves of $\mathrm{N}=2.35$ and $\mathrm{N}=2.45$. Therefore, it could be considered that the particle size correction factor of marine sediments at the depth of $1600 \mathrm{~m}$ below the sea level in the Shenhu Area of South China Sea was about 2.40 . 


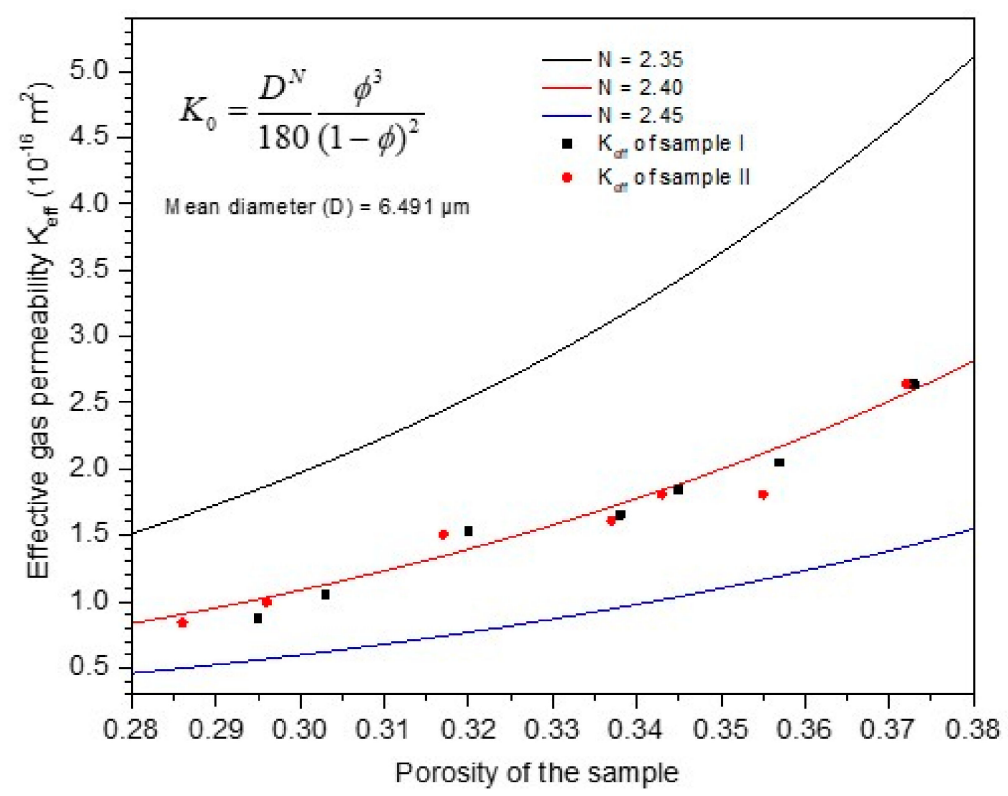

Figure 7. The relationship between the effective gas permeability and the porosity of the sample.

\section{Numerical Models and Simulation Approach}

\subsection{Geometry and Well Design}

Figure 8 shows the geometry schematic diagram of simulation domains. The enlarged permeable well wall was surrounding the vertical production well in the production interval. There were three hydrate-bearing layers (HBLs) between the overburden (OB) and underburden (UB). The thickness of HBL-I, HBL-II, and HBL-III were $35 \mathrm{~m}, 15 \mathrm{~m}$, and $27 \mathrm{~m}$, respectively. The bottom of HBL-III was at the depth of $1572 \mathrm{~m}$ below sea level. The OB and UB had the same thickness of $\Delta Z=20 \mathrm{~m}$, which was large enough to provide precise estimates of pressure and heat transfer in the hydrate deposit $[7,20]$. The radius and height of the cylindrical simulation domains were $145 \mathrm{~m}$ and $117 \mathrm{~m}$, respectively. Considering the symmetry, only half of simulation domains were used for simulation calculation. The vertical production well was positioned at the center of the cylindrical simulation domains and parallel to the axial direction. The radius of production well $\left(r_{\mathrm{w}}\right)$ was $0.1 \mathrm{~m}$, the production well was assumed to have the permeability of $k=5.0 \times 10^{-9} \mathrm{~m}^{2}$ (5000 Darcies), the porosity was $\phi=1.0$, and the capillary pressure was $P_{\text {cap }}=0[10,40]$. 


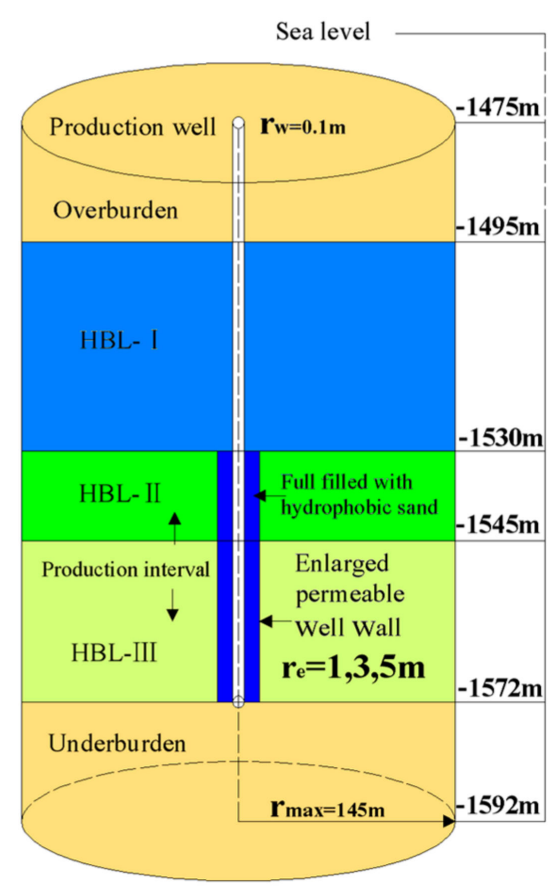

Figure 8. The schematic of simulation domains and the enlarged permeable well wall design.

The core analysis and well logging data at the site of W-17 indicated HBL-II and HBL-III were the most active section, where the pressure and temperature were closest to NGH phase equilibrium curve [29]. Hence, the HBL-II and HBL-III were employed as production intervals, because both of them were ideal gas hydrate production layers. As shown in Figure 8, the enlarged permeable well wall filled with hydrophobic sand was surrounding the vertical production well in the production interval. Furthermore, the enlarged permeable well wall was realized by the directional hydraulic fracturing technology, and the porous hydrophobic materials was injected into the artificial crack to form a relatively high-permeability zone with specific radius. The intrinsic permeability inside the enlarged permeable well wall was assumed to have $k=5 \times 10^{-13} \mathrm{~m}^{2}(0.5 D)$.

\subsection{Domain Discretization, System Properties, and Initial Conditions}

The simulation results were calculated by the parallel version of the TOUGH + HYDRATE $(T+H)$ code. The geologic system was arranged on the basis of hydrate deposits at the site of $\mathrm{W}-17$ in South China Sea [29]. Table 1 shows the system properties and initial conditions used in this simulation model. The HBL-II and HBL-III were used for gas production and the HBL-I was used as natural barriers. As shown in Figure 9, the radial direction $R$ was divided into 81 grids, the discretization along the radial direction was non-uniform, and the first grid was $0.1 \mathrm{~m}$ followed by logarithmical increase. The axial direction $Z$ was divided into 194 grids; a very fine discretization $(\Delta Z=0.5 \mathrm{~m})$ was used in HBLs and a coarser discretization $(\Delta Z=1.0 \mathrm{~m})$ was used in $\mathrm{OB}$ and UB. This fine discretization was sufficient to accurately describe the heat and pressure transfer and spatial distributions of characteristic parameters in the deposit. Hence, the cylindrical domain system was discretized into $81 \times 194=15,714$ grid blocks in $(R, Z)$ direction. The number of active grid blocks was 14,140, and the remaining grid blocks were the inactive steel and boundary elements, which included the uppermost and lowermost layers with the constant pressure and temperature conditions. 
Table 1. The physical properties and conditions of hydrate reservoir at site W-17.

\begin{tabular}{|c|c|}
\hline Parameter & Value \\
\hline Thickness of OB and UB & $20.0 \mathrm{~m}$ \\
\hline Thickness of HBL-I, II and III & $35.0,15$, and $27 \mathrm{~m}$ \\
\hline Distance of production interval & $42.0 \mathrm{~m}$ \\
\hline Position of HBL-III below the sea level & $1572 \mathrm{~m}$ \\
\hline Initial pressure $P_{\mathrm{B}}$ & $15.8 \mathrm{MPa}$ \\
\hline Initial temperature $T_{\mathrm{B}}$ & $289.38 \mathrm{~K}$ \\
\hline Initial saturation in the HBL-I & $S_{\mathrm{H}}=0.34, S_{\mathrm{A}}=0.66, S_{\mathrm{G}}=0.60$ \\
\hline Initial saturation in the HBL-II & $S_{\mathrm{H}}=0.31, S_{\mathrm{A}}=0.612, S_{\mathrm{G}}=0.078$ \\
\hline Initial saturation in the HBL-III & $S_{\mathrm{H}}=0.00, S_{\mathrm{A}}=0.922, S_{\mathrm{G}}=0.078$ \\
\hline Gas composition & $100 \% \mathrm{CH}_{4}$ \\
\hline Geothermal gradient $G$ & $0.045 \mathrm{~K} / \mathrm{m}$ \\
\hline Water salinity & $3.05 \%$ \\
\hline Intrinsic permeability of $\mathrm{HBL}, \mathrm{OB}, \mathrm{UB}\left(k_{\mathrm{x}}=k_{\mathrm{y}}=k_{\mathrm{z}}\right)$ & $1.53 \times 10^{-16} \mathrm{~m}^{2}$ \\
\hline Permeability inside the well & $5 \times 10^{-9} \mathrm{~m}^{2}(5000 \mathrm{D})$ \\
\hline Permeability inside enlarged permeable well & $5 \times 10^{-12} \mathrm{~m}^{2}(0.5 \mathrm{D})$ \\
\hline Porosity $f$ of OB and UB & 0.35 and 0.32 \\
\hline Porosity $f$ of HBL-I, II and III & $0.35,0.33$ and 0.32 \\
\hline Wet thermal conductivity $k_{\Theta R W}$ & $3.1 \mathrm{~W} / \mathrm{m} / \mathrm{K}$ \\
\hline Dry thermal conductivity $k_{\Theta R D}$ & $1.0 \mathrm{~W} / \mathrm{m} / \mathrm{K}$ \\
\hline Composite thermal conductivity Model [7] & $\begin{array}{c}k_{\Theta C}=k_{\Theta R D} \\
+\left(S_{\mathrm{A}}^{1 / 2}+S_{\mathrm{H}}^{1 / 2}\right)\left(k_{\Theta R W}-k_{\Theta \mathrm{RD}}\right)+\phi S_{\mathrm{I}} k_{\Theta \mathrm{I}}\end{array}$ \\
\hline Capillary pressure model [41] & $\begin{array}{c}P_{\text {cap }}=-P_{01}\left[\left(S^{*}\right)^{-1 / \lambda}-1\right] \\
S^{*}=\left(S_{\mathrm{A}}-S_{\mathrm{irA}}\right) /\left(S_{\mathrm{mxA}}-S_{\mathrm{irA}}\right)\end{array}$ \\
\hline$S_{\text {irA }}$ & 0.30 \\
\hline$S_{\mathrm{irG}}$ & 0.05 \\
\hline$\lambda$ & 0.45 \\
\hline$P_{0}$ & $\begin{array}{c}105 \mathrm{~Pa} \\
k_{\mathrm{rA}}=\left(S_{A}^{*}\right)^{n}\end{array}$ \\
\hline Relative permeability Model [7] & $\begin{array}{c}k_{\mathrm{rG}}=\left(S_{\mathrm{G}}^{*}\right)^{n G} \\
S_{\mathrm{A}}^{*}=\left(S_{\mathrm{A}}-S_{\mathrm{irA}}\right) /\left(1-S_{\mathrm{irA}}\right) \\
S_{\mathrm{G}}^{*}=\left(S_{\mathrm{G}}-S_{\mathrm{irG}}\right) /\left(1-S_{\mathrm{irA}}\right)\end{array}$ \\
\hline$n$ & $\begin{array}{lll}G & 5.0\end{array}$ \\
\hline$n G$ & 3.5 \\
\hline
\end{tabular}

The initial conditions used in the model were calculated by the methods described by Li et al. [11,20]. The base of the HBL-III was at the depth of $1572 \mathrm{~m}$ under the sea level. The initial pressure and temperature at the bottom of the HBL-III were initialized to be $15.8 \mathrm{MPa}$ and $289.38 \mathrm{~K}$, respectively (as shown in Table 1). The mean effective porosities of HBL-I, HBL-II, and HBL-III were $35 \%, 33 \%$, and $32 \%$, respectively. The pore space within HBL-I was filled with liquid water and solid NGH (mean hydrate saturation $\mathrm{S}_{\mathrm{H}}=34 \%$ ). The pore space within HBL-II was filled with liquid water, solid NGH (mean $S_{\mathrm{H}}=31 \%$ ), and free hydrocarbon (mean gas saturation $S_{\mathrm{G}}=7.8 \%$ ). The pore space within HBL-III was filled with liquid water and free hydrocarbon (mean $S_{\mathrm{G}}=7.8 \%$ ). The basic parameters were based on field measurement [29]. 

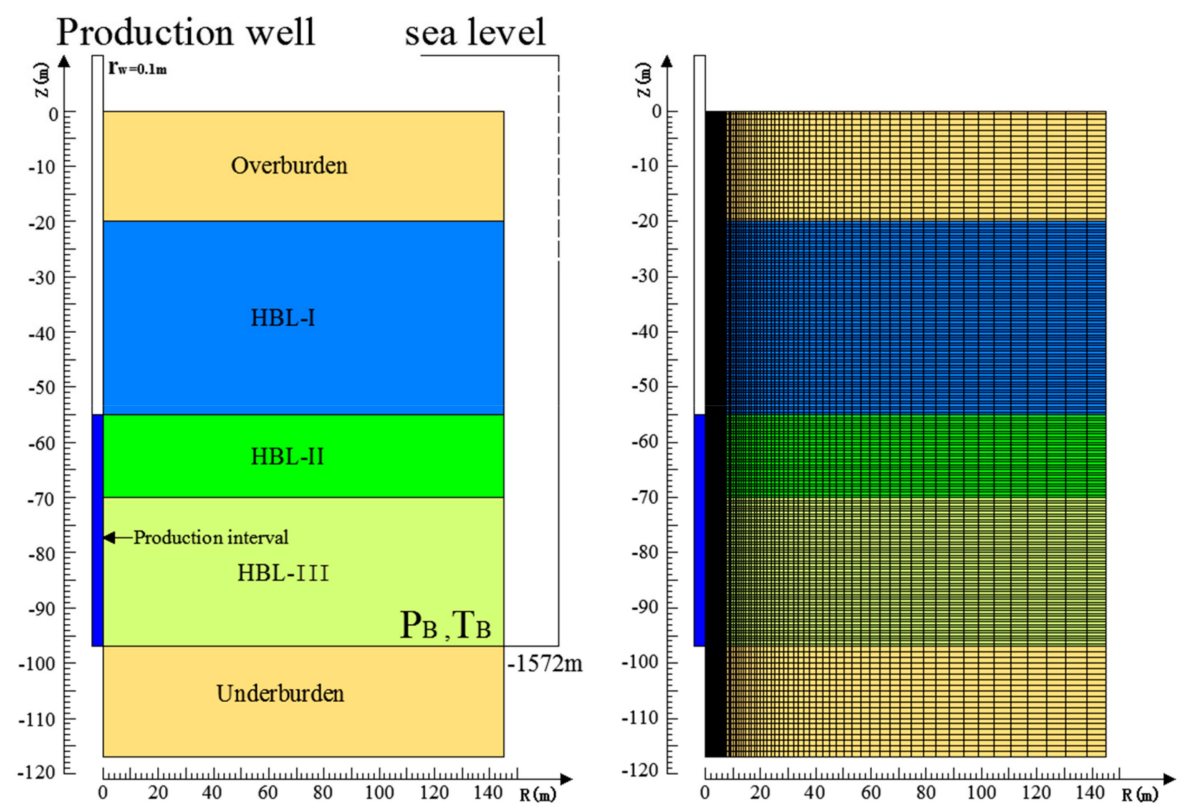

Figure 9. Configuration of the hydrate deposit, and the corresponding 2D hybrid mesh.

\section{Simulation Results}

\subsection{Gas Production}

Figure 10 shows the cumulative volume $\left(V_{\mathrm{p}}\right)$ and volumetric rate $\left(Q_{\mathrm{p}}\right)$ of methane production from the well. The depressurization method was employed in all four cases, and the production pressure $P_{\mathrm{W}}$ was set to be $3.0 \mathrm{MPa}$ in each case. In these four cases, the $V_{\mathrm{P}}$ curves were all characterized by a continuous rise during the 30-year production period, and the $Q_{\mathrm{p}}$ curves showed a rapid decline from each highest value in a short time. In the case without the enlarged permeable well wall, the total $V_{\mathrm{p}}$ was about $1.46 \times 10^{6} \mathrm{~m}^{3}$ under the standard state (ST) during the 30-year production period, the maximum $Q_{\mathrm{p}}$ was approximately $600 \mathrm{~m}^{3}$ per day in the first few days, and then gradually decreased to $89 \mathrm{~m}^{3}$ per day after 30 years. In the case with the enlarged permeable well wall radius of $5 \mathrm{~m}$, the total $V_{\mathrm{p}}$ was about $3.89 \times 10^{6} \mathrm{ST} \mathrm{\textrm {m } ^ { 3 }}$, the maximum $Q_{\mathrm{p}}$ was more than $1800 \mathrm{~m}^{3}$ per day in the first few days, and then gradually decreased to $215 \mathrm{~m}^{3}$ per day at the end of 30-year production period. The results indicated that the $V_{\mathrm{p}}$ increased by 2.7 times, and the $Q_{\mathrm{p}}$ increased by 2.4 times as the permeable well wall radius increase from 0 to $5 \mathrm{~m}$. In other words, the larger the permeable well wall radius, the larger amount of gas and the volumetric rate we would obtain, which indicated that the influence of enlarged permeable well wall on hydrate dissociation was obvious. Meanwhile, it showed a stable production rate after 4500 days, which indicated that the hydrate dissociation process tended to be steady.

\subsection{Water Production and Gas-to-Water Ratio}

Figure 11 shows the cumulative mass of produced water $\left(M_{W}\right)$ and the mass rate of water production $\left(Q_{\mathrm{W}}\right)$ from the production well. In these four cases, the $M_{\mathrm{W}}$ curves were all characterized by a continuous rise during the 30-year production period, and $Q_{\mathrm{W}}$ curves showed a rapid decline from each highest value in a short time; this phenomenon was consistent with the analysis of gas production. In the case without the enlarged permeable well wall, the $M_{\mathrm{W}}$ curve was close to a straight line, which indicated that the water production rate was basically constant. However, in the case with the enlarged permeable well wall radius of $5 \mathrm{~m}$, the $M_{\mathrm{W}}$ curve had a tendency to exaggerate, which indicated that the water production would continue to increase. At the end of 30-year production period, the total $M_{\mathrm{W}}$ increased from $4.6 \times 10^{7} \mathrm{~kg}$ to $2.0 \times 10^{8} \mathrm{~kg}$ as the permeable well wall radius 
increased from 0 to $5 \mathrm{~m}$, which indicated that the total $M_{\mathrm{W}}$ increased by 4.3 times. Meanwhile, the $Q_{\mathrm{W}}$ was $110 \mathrm{~kg}$ per day in the case without enlarged permeable well wall, and increased by 2.2 times in the case with the enlarged permeable well wall radius $5 \mathrm{~m}$. Comparing the increase of $Q_{\mathrm{W}}$ and $M_{\mathrm{W}}$, the $M_{\mathrm{W}}$ was mainly produced in the early stage of production, which indicated that the effect of enlarged permeable well wall on the early stage of production was better than that in the later stage of production.

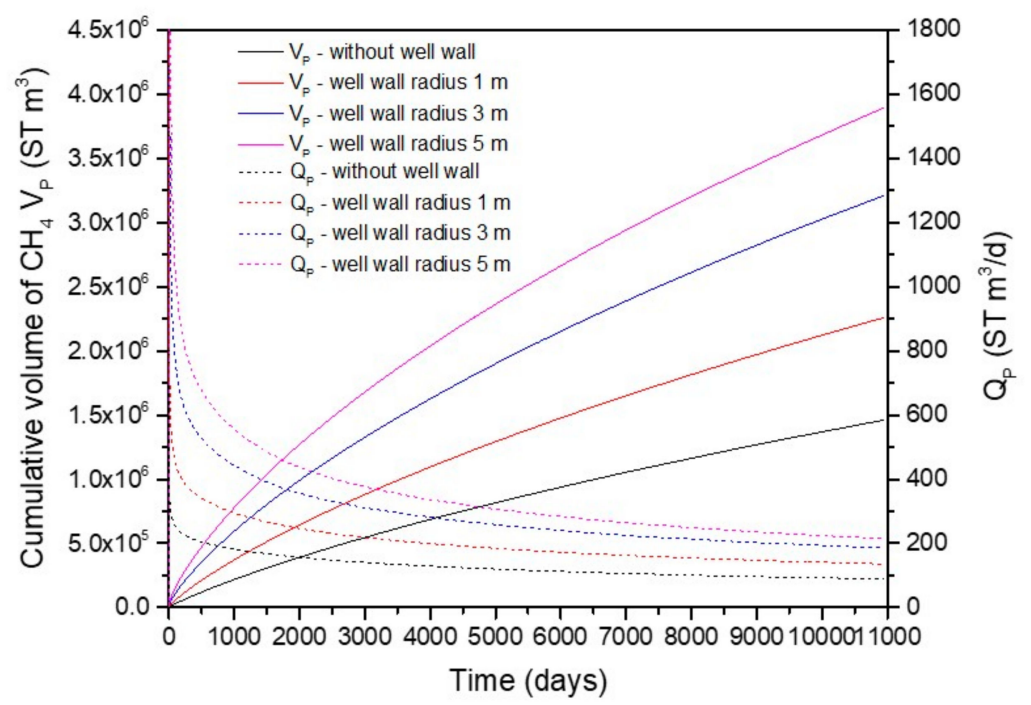

Figure 10. The cumulative volume $\left(V_{\mathrm{p}}\right)$ and volumetric rate $\left(Q_{\mathrm{p}}\right)$ of gas production.

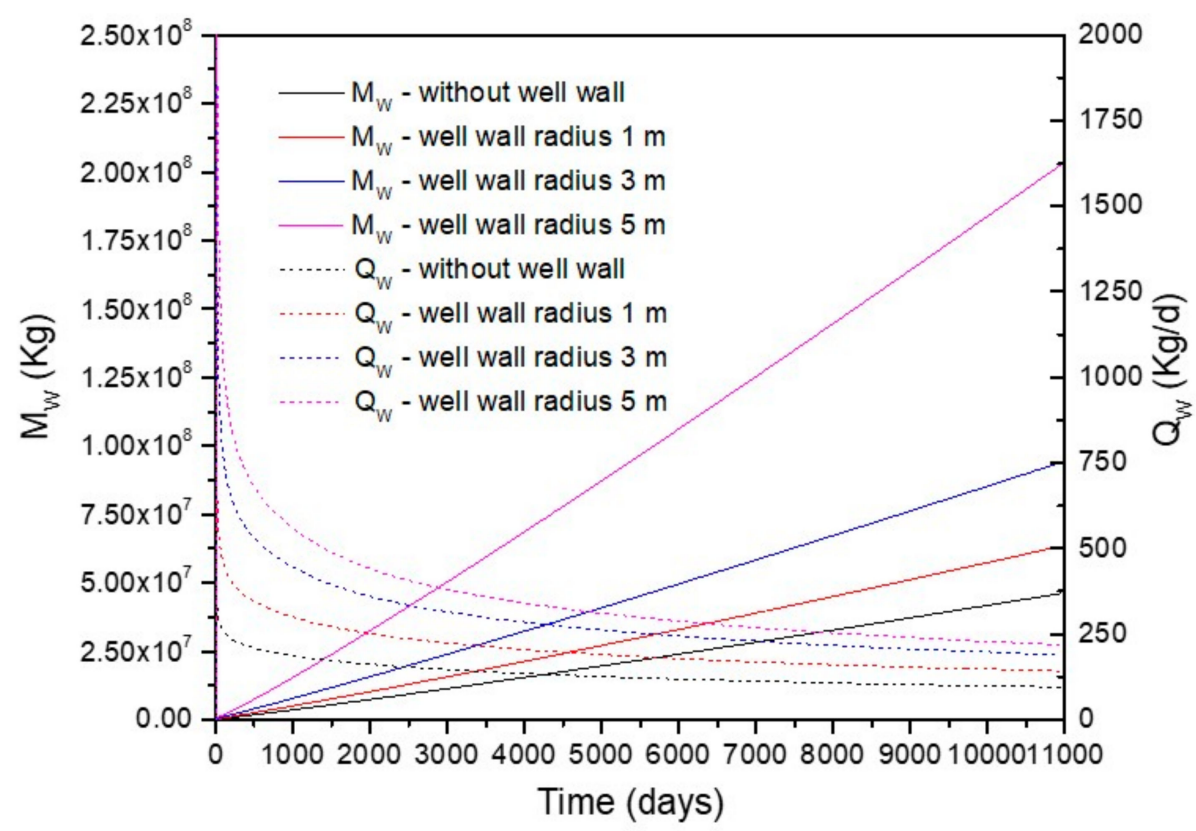

Figure 11. The cumulative mass of produced water $\left(M_{\mathrm{W}}\right)$ and the water production rate $\left(Q_{\mathrm{W}}\right)$.

Figure 12 shows the evolution of the gas-to-water ratio $\left(R_{\mathrm{GW}}\right)$ during gas production from the production well with different circumferential radii. The $R_{\mathrm{GW}}$ was calculated to be $R_{\mathrm{GW}}=1000 V_{\mathrm{P}} / M_{\mathrm{W}}$. In these four cases, the $R_{\mathrm{GW}}$ curves rose sharply in the first few days and then decreased to a lower level gradually. As shown in Figure 12, the maximum $R_{\mathrm{GW}}$ of four cases was 106 (well wall radius $3 \mathrm{~m}$ ). In the first 2000 days, the $R_{\mathrm{GW}}$ of the case with the enlarged permeable well wall radius of $3 \mathrm{~m}$ was the highest among the four cases, and then the $R_{\mathrm{GW}}$ of the case with well wall radius of $1 \mathrm{~m}$ became 
the largest. The simulation results indicated that the ideal maximum value of $R_{\mathrm{GW}}$ was between the cases with the enlarged permeable well wall radius from 1 to $3 \mathrm{~m}$. Meanwhile, $R_{\mathrm{GW}}$ maintained stable after 4500 days, which was consistent with the $Q_{\mathrm{p}}$ mentioned above. The $R_{\mathrm{GW}}$ in the case with the enlarged permeable well wall radius of $5 \mathrm{~m}$ was 19.2 at the end of 30-year period, which was only a half of that in the case with the enlarged permeable well wall radius of $1 \mathrm{~m}$. This proved that the production potential with the enlarged permeable well wall radius of $1 \mathrm{~m}$ was more promising in the relative criterion.

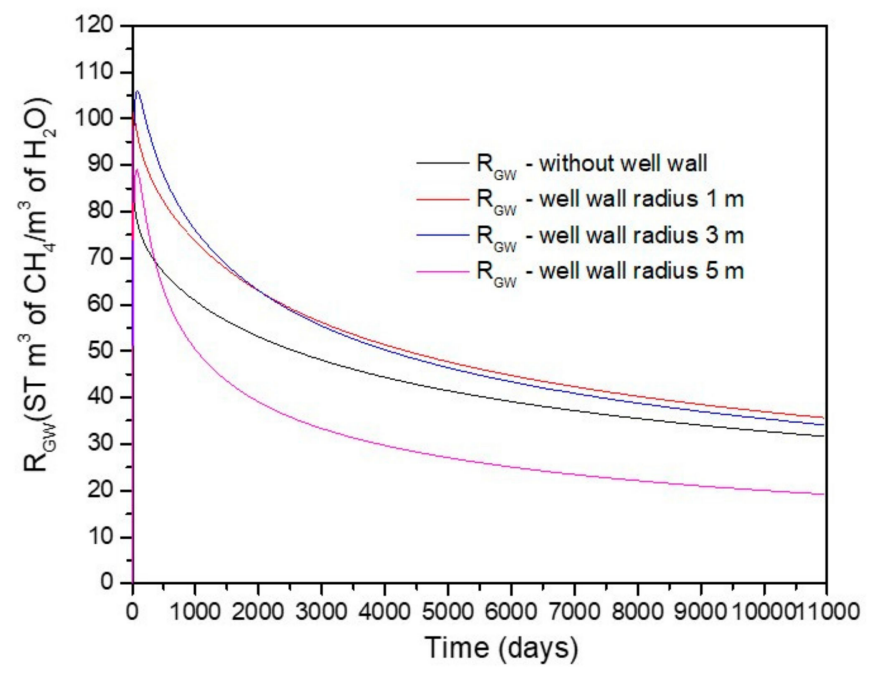

Figure 12. Gas-to-water ratio $\left(R_{\mathrm{GW}}\right)$ produced from the production well.

\subsection{Spatial Distributions of Characteristic Parameters}

\subsubsection{Spatial Distributions of $S_{\mathrm{H}}$}

Figure 13 shows the evolution of the spatial distributions of $S_{\mathrm{H}}$ during the 30-year production period in the case with the enlarged permeable well wall radius of $5 \mathrm{~m}$. The selected time points were $\mathrm{t}=60$ days, 1 year, 5 years, 10 years, 20 years, and 30 years, corresponding to Figure 13a-f, respectively. The $S_{\mathrm{H}}$ spatial distributions over time provided a measure to evaluate the hydrate decomposition compared with the initial HBL. In initial state, the pore space within HBL-I $(-20 \mathrm{~m}<Z<-55 \mathrm{~m})$ was filled with liquid water and solid NGH (mean $\left.S_{\mathrm{H}}=31 \%\right)$. The pore space within HBL-II $(-55 \mathrm{~m}<$ $Z<-70 \mathrm{~m}$ ) was filled with liquid water, solid NGH (mean $S_{\mathrm{H}}=31 \%$ ), and free hydrocarbon (mean $S_{\mathrm{G}}=7.8 \%$ ). In the first few 60 days, a small cylindrical region with the hydrate dissociated around the enlarged permeable well wall was formed, and the hydrate was basically not dissociated within HBL-I. However, at the end of 30-year production period, the radius of hydrate decomposition region within HBL-I and HBL-II were about 20 and $35 \mathrm{~m}$, respectively. Meanwhile, secondary hydrate formation occurred in the interface of the HBL-I and HBL-II, which was taken as natural barriers to prevent the low-temperature water invasion from the $\mathrm{OB}$. The hydrate decomposition rate at the bottom of the HBL-II was larger than that of the upper part, which mainly due to the influence of the geothermal gradient. 


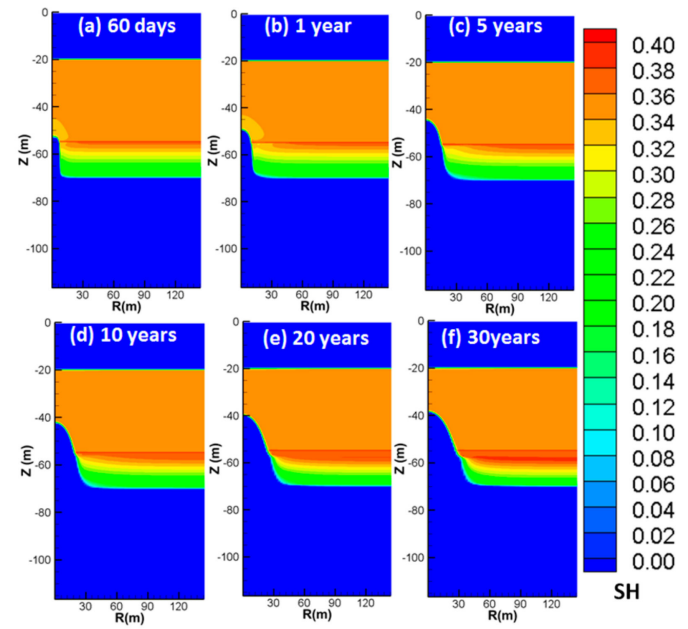

Figure 13. Spatial distribution evolution of hydrate saturation $S_{\mathrm{H}}$ during hydrate dissociation (well wall radius $5 \mathrm{~m}$ ).

\subsubsection{Spatial Distributions of $S_{\mathrm{G}}$}

Figure 14 shows the evolution of the spatial distributions of $S_{G}$ during the 30-year production period in the case with the enlarged permeable well wall radius of $5 \mathrm{~m}$. In initial state, the pore space within HBL-III $(-70 \mathrm{~m}<Z<-97 \mathrm{~m})$ was filled with liquid water and free hydrocarbon mean $\left(S_{\mathrm{G}}=7.8 \%\right)$. The mean $S_{\mathrm{G}}$ within the HBL-II was employed as $7.8 \%$ in the initial state as well. The originating undissociated hydrate between the interface HBL-I and HBL-II functioned as a barrier to prevent the gas and fluid flow because of its low permeability. In the early stage of about 10 years, the gas saturation in the production well could maintain a relatively high level, and then gradually decreased to a level close to the hydrate layer saturation. The free gas saturation within the HBL-I was very limited after 1 year because of the very little hydrate decomposition, and then the hydrate near the production well began to decompose gradually. At the end of the 30-year production period, the radius of hydrate dissociated cylindrical region at the interface of HBL-I and HBL-II was about $30 \mathrm{~m}$, but the height within the HBL-I was only close to $15 \mathrm{~m}$, which indicated the hydrate dissociation of HBL-I was still at a low level. The gas saturation had a significant increase between the HBL-II and HBL-III, which indicated the free gas of HBL-III gradually diffused to the HBL-II with the increase of production period.

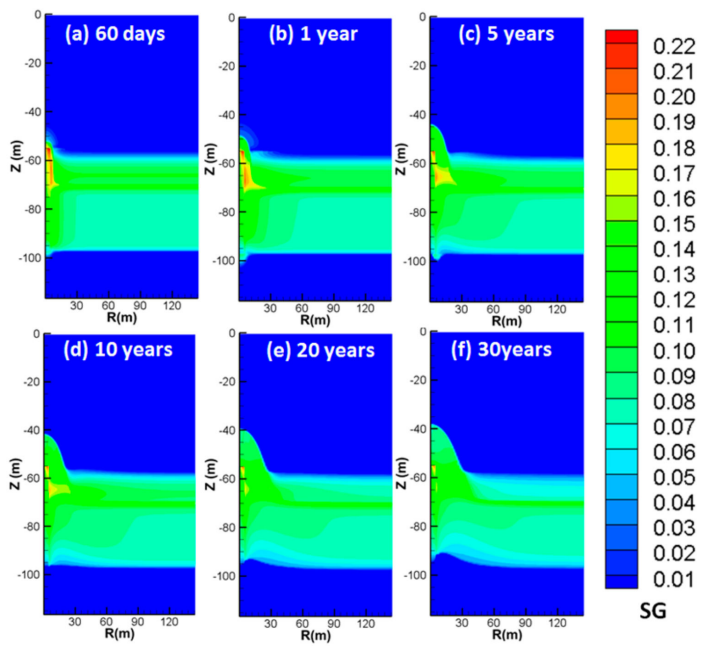

Figure 14. Spatial distribution evolution of gas saturation $S_{\mathrm{G}}$ during hydrate dissociation (well wall radius $5 \mathrm{~m})$. 


\subsubsection{Spatial Distributions of $P$}

Figure 15a-f shows the evolution of the $P$ spatial distributions over time in the case with the enlarged permeable well wall radius $5 \mathrm{~m}$. The pressure gradient propagated from the HBL to the $\mathrm{OB}$ and $\mathrm{UB}$ in the middle to late production periods. In 60 days, the hydrate dissociation caused by depressurization only affected a small area near the production interval. The pressure of OB was basically constant, which indicated that $\mathrm{OB}$ as a barrier layer played a very good protective role to prevent the invasion of the upper seawater. At the end of the 30-year production period, the pressure distribution was basically stable, which indicated that the gas and water two-phase flow process in the whole hydrate reservoir was relatively stable. Meanwhile, the pressure propagation radius within the HBL-I reached $60 \mathrm{~m}$, which indicated that the hydrate in the HBL-I was also in a decomposed state. Comparing the spatial distributions of $S_{\mathrm{H}}$ and $P$, the pressure of hydrate was lower than the condition of phase equilibrium for a period of time before decomposition. That was to say, the driving force of depressurization broke down the original condition of phase equilibrium and stability, which resulted in the decomposition of hydrate reservoirs.

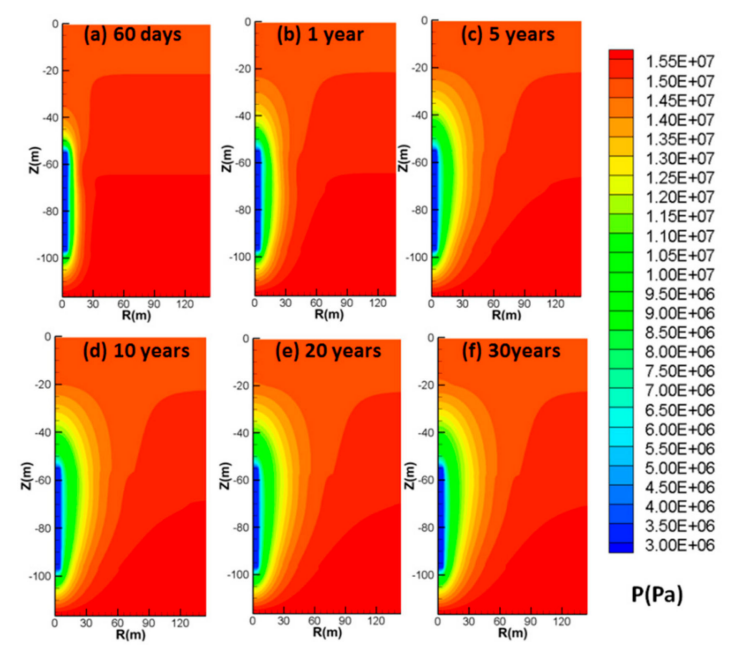

Figure 15. Spatial distribution evolution of $P$ during hydrate dissociation (well wall radius $5 \mathrm{~m}$ ).

\subsubsection{Spatial Distributions of $T$}

Figure 16 shows the evolution of the $T$ spatial distributions over time in the case with the enlarged permeable well wall radius of $5 \mathrm{~m}$. The evolutions of temperature $T$ provided the effects of the environmental impacts. As shown in Figure 16a, the temperatures around the production well within the HBL-II decreased sharply, which was due to the sensible heat adsorption by the hydrate decomposition. In the first five years of the production period, there was an obvious temperature drop area around the production well within the HBL-II, and then it gradually rose to a level close to the original formation. The fluctuation of temperature was mainly concentrated within the HBL-II, which indicated that the HBL-II was the main hydrate decomposition layer. The rapid decrease of temperature within the HBL-II absorbed a lot of heat, which was the main reason for the formation of secondary hydrate. The flow of free gas from the HBL-III into the production well brought a lot of heat, which played an important role in preventing the formation of secondary hydrate in the production interval. Therefore, simultaneous exploitation of the HBL-II and HBL-III was an effective way to solve the secondary hydrate problem. 


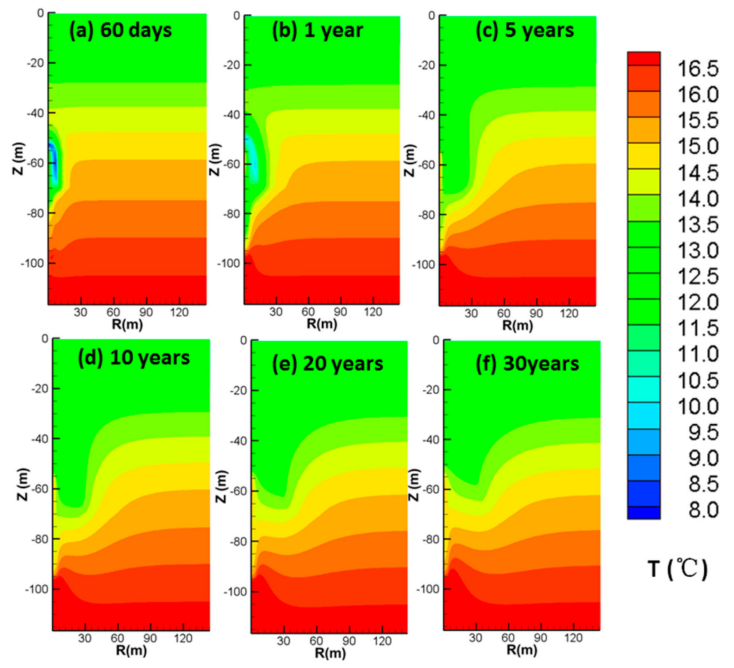

Figure 16. Spatial distribution evolution of $T$ during hydrate dissociation (well wall radius $5 \mathrm{~m}$ ).

\section{Conclusions}

In this work, we performed a comprehensive work on the evaluation of gas production of hydrate deposits in the South China Sea. This work includes the measurement of gas permeability of the sediments in the South China Sea, the numerical simulation of gas and water production characteristics at the site of $\mathrm{W}-17$, and the a new method of increasing the permeability around the production well to improve the gas production efficiency.

The intrinsic permeability of natural sediments was determined to be $1.53 \times 10^{-16} \mathrm{~m}^{2}$ with the confining pressures of $P_{C}=15 \mathrm{MPa}$ and porosity of $32.00 \%$, and the gas permeability was very sensitive to the confining pressure.

The effective gas permeability of the natural sediments sample decreased from $2.638 \times 10^{-16} \mathrm{~m}^{2}$ to $0.872 \times 10^{-16} \mathrm{~m}^{2}$ as the confining pressure increased from $2 \mathrm{MPa}$ to $23 \mathrm{MPa}$. The porosity of the natural sediments sample decreased from $41.82 \%$ to $29.54 \%$ as the confining pressure increased from 0 to $23 \mathrm{MPa}$.

The particle size term in the classical Kozeny-Carman equation was revised by a correction factor $(\mathrm{N})$, and the experimental results fitted well with the curves when $\mathrm{N}$ value was 2.40 .

In the case without the enlarged permeable well wall, the total $V_{\mathrm{p}}$ and $M_{\mathrm{W}}$ were about $1.46 \times 10^{6} \mathrm{~m}^{3}$ and $4.6 \times 10^{7} \mathrm{~kg}$ under standard state (ST) after 30 years, respectively. The $V_{\mathrm{p}}$ and $M_{\mathrm{W}}$ increased by 2.7 and 4.3 times as the permeable well wall radius increased from 0 to $5 \mathrm{~m}$, respectively.

The $R_{\mathrm{GW}}$ in the case with the enlarged permeable well wall radius $5 \mathrm{~m}$ was 19.2 at the end of 30-year period, which was only half of that in the case with the enlarged permeable well wall radius $1 \mathrm{~m}$. This proved that the production potential with the enlarged permeable well wall radius $1 \mathrm{~m}$ was more promising in the relative criterion.

The influence of the enlarged permeable well wall on hydrate dissociation was obvious. The larger the permeable well wall radius, the larger amount of gas and the volumetric rate we would obtain. The free gas of HBL-III gradually diffused to the HBL-II with the increase of production period. Simultaneous exploitation of the HBL-II and HBL-III was an effective way to solve the secondary hydrate problem.

Author Contributions: All the authors contributed to publish this paper. The main research idea was contributed by X.L., G.L. and P.S.; P.S. and X.L. wrote the paper; J.Z. contributed on the simulation works; J.L. prepared for the experiments. All authors revised and approved the publication of the paper.

Funding: This research was funded by the National Natural Science Foundation of China $(51736009,51976228$, 51676196), Key Research Program of Frontier Sciences, CAS (QYZDB-SSW-JSC028, QYZDJ-SSW-JSC033), the National Key R\&D Program of China (2017YFC0307306, 2016YFC0304002), and Special Project for Marine Economy Development of Guangdong Province (GDME-2018D002). 
Acknowledgments: The authors are very grateful for the support of the National Natural Science Foundation of China (51736009, 51976228, 51676196), Key Research Program of Frontier Sciences, CAS (QYZDB-SSW-JSC028, QYZDJ-SSW-JSC033), the National Key R\&D Program of China (2017YFC0307306, 2016YFC0304002), and Special Project for Marine Economy Development of Guangdong Province (GDME-2018D002), which are gratefully acknowledged.

Conflicts of Interest: The authors declare no conflict of interest.

\section{Nomenclature}

G thermal gradient within the frozen layer $\left({ }^{\circ} \mathrm{C} / \mathrm{m}\right)$

$k \quad$ intrinsic permeability $\left(\mathrm{m}^{2}\right)$

$k_{\text {eff }} \quad$ effective permeability $\left(\mathrm{m}^{2}\right)$

$k_{\mathrm{rA}} \quad$ aqueous relative permeability $\left(\mathrm{m}^{2}\right)$

$k_{\mathrm{rG}} \quad$ gas relative permeability $\left(\mathrm{m}^{2}\right)$

$\mathrm{k}_{\Theta \mathrm{C}} \quad$ thermal conductivity $(\mathrm{W} / \mathrm{m} / \mathrm{K})$

$k_{\Theta R D} \quad$ thermal conductivity of dry porous medium $(\mathrm{W} / \mathrm{m} / \mathrm{K})$

$k_{\Theta R W}$ thermal conductivity of fully saturated porous medium $(\mathrm{W} / \mathrm{m} / \mathrm{K})$

$P \quad$ pressure $(\mathrm{Pa})$

$P_{\mathrm{B}} \quad$ initial pressure at base of $\mathrm{HBL}(\mathrm{Pa})$

$P_{0} \quad$ atmosphere pressure $(\mathrm{Pa})$

$P W \quad$ pressure at the well $(\mathrm{Pa})$

$\Delta P_{\mathrm{W}} \quad$ driving force of depressurization, $P_{\mathrm{W} 0}-P_{\mathrm{W}}(\mathrm{Pa})$

$V_{\mathrm{P}} \quad$ cumulative volume of produced $\mathrm{CH}_{4}\left(\mathrm{ST} \mathrm{m}^{3}\right)$

$M_{\mathrm{W}} \quad$ cumulative mass of produced water $(\mathrm{kg})$

$Q_{\mathrm{P}} \quad$ volumetric rate of methane production at the well $\left(\mathrm{ST} \mathrm{m}^{3} / \mathrm{d}\right)$

$Q_{\mathrm{W}} \quad$ water mass production rate at the well $(\mathrm{kg} / \mathrm{d})$

$R_{\mathrm{GW}}$ gas-to-water production ratio $\left(\mathrm{ST} \mathrm{m}^{3}\right.$ of $\mathrm{CH}_{4} / \mathrm{m}^{3}$ of $\mathrm{H}_{2} \mathrm{O}$ )

$R, Z \quad$ cylindrical coordinates $(\mathrm{m})$

$\Delta R \quad$ discretization along the $\mathrm{R}$-axis (m)

$\Delta \mathrm{Z}$ discretization along the $\mathrm{Z}$-axis $(\mathrm{m})$

$r_{\max }$ maximum radius of the simulation domain $(\mathrm{m})$

$r_{\mathrm{W}} \quad$ production well radius (m)

$r_{\mathrm{e}} \quad$ radius of the permeable well wall (m)

$S$ phase saturation

$t$ time (days)

$T$ temperature $\left({ }^{\circ} \mathrm{C}\right)$

$T_{\mathrm{B}} \quad$ initial temperature at the base of $\operatorname{HBL}\left({ }^{\circ} \mathrm{C}\right)$

$X_{\mathrm{S}} \quad$ salinity

$\Delta H_{\mathrm{C}} \quad$ combustion enthalpy of produced methane (J)

$\Phi \quad$ porosity

$\lambda \quad$ van Genuchten exponent-Table 1

Subscripts and superscripts

0 denotes initial state

A aqueous phase

B base of HBL

cap capillary

G gas phase

$\mathrm{H} \quad$ solid hydrate phase

IrA irreducible aqueous phase

irG irreducible gas

$\mathrm{n} \quad$ permeability reduction exponent-Table 1

nG gas permeability reduction exponent-Table 1

OB overburden

UB underburden

W well 


\section{References}

1. Sloan, E.D.; Koh, C.A. Clathrate Hydrates of Natural Gases, 3rd ed.; CRC Press: Boca Raton, FL, USA, 2007.

2. Konno, Y.; Fujii, T.; Sato, A.; Akamine, K.; Naiki, M.; Masuda, Y.; Yamamoto, K.; Nagao, J. Key findings of the world's first offshore methane hydrate production test off the coast of Japan: Toward future commercial production. Energy Fuels 2017, 31, 2607-2616. [CrossRef]

3. Makogon, Y.F.; Holditch, S.A.; Makogon, T.Y. Natural gas-hydrates-A potential energy source for the 21st Century. J. Petrol. Sci. Eng. 2007, 56, 14-31. [CrossRef]

4. Makogon, Y.F. Natural gas hydrates-A promising source of energy. J. Nat. Gas. Sci. Eng. 2010, 2, 49-59. [CrossRef]

5. Chong, Z.R.; Yang, S.H.B.; Babu, P.; Linga, P.; Li, X.S. Review of natural gas hydrates as an energy resource: Prospects and challenges. Appl. Energy 2016, 162, 1633-1652. [CrossRef]

6. Moridis, G.J.; Reagan, M.I.; Kim, S.J.; Seol, Y.; Zhang, K. Evaluation of the gas production potential of marine hydrate deposits in the Ulleung Basin of the Korean East Sea. SPE J. 2009, 14, 759-781. [CrossRef]

7. Moridis, G.J.; Kowalsky, M.B.; Pruess, K. Depressurization-induced gas production from class 1 hydrate deposits. SPE Reserv. Eval. Eng. 2007, 10, 458-481. [CrossRef]

8. Li, B.; Li, X.S.; Li, G.; Feng, J.C.; Wang, Y. Depressurization induced gas production from hydrate deposits with low gas saturation in a pilot-scale hydrate simulator. Appl. Energy 2014, 129, 274-286. [CrossRef]

9. Ahmadi, G.; Ji, C.A.; Smith, D.H. Production of natural gas from methane hydrate by a constant downhole pressure well. Energy Convers. Manag. 2007, 48, 2053-2068. [CrossRef]

10. Li, G.; Moridis, G.J.; Zhang, K.; Li, X.S. The use of huff and puff method in a single horizontal well in gas production from marine gas hydrate deposits in the Shenhu Area of South China Sea. J. Petrol. Sci. Eng. 2011, 77, 49-68. [CrossRef]

11. Li, X.S.; Li, B.; Li, G.; Yang, B. Numerical simulation of gas production potential from permafrost hydrate deposits by huff and puff method in a single horizontal well in Qilian Mountain, Qinghai province. Energy 2012, 40, 59-75. [CrossRef]

12. Li, S.; Zhang, L.; Jiang, X.; Li, X. Hot-brine injection for the dissociation of natural gas hydrates. Pet. Sci. Technol. 2013, 31, 1320-1326. [CrossRef]

13. Li, G.; Li, X.S.; Tang, L.G.; Zhang, Y. Experimental investigation of production behavior of methane hydrate under ethylene glycol stimulation in unconsolidated sediment. Energy Fuels 2007, 21, 3388-3393. [CrossRef]

14. Yuan, Q.; Sun, C.Y.; Yang, X.; Ma, P.C.; Ma, Z.W.; Li, Q.P. Gas production from methane-hydrate-bearing sands by ethylene glycol injection using a three-dimensional reactor. Energy Fuels 2011, 25, 3108-3115. [CrossRef]

15. Lee, J. Experimental study on the dissociation behavior and productivity of gas hydrate by brine injection scheme in porous rock. Energy Fuels 2010, 24, 456-463. [CrossRef]

16. Ota, M.; Morohashi, K.; Abe, Y.; Watanabe, M.; Smith, R.L.; Inomata, H. Replacement of $\mathrm{CH}_{4}$ in the hydrate by use of liquid $\mathrm{CO}_{2}$. Energy Convers. Manag. 2005, 46, 1680-1691. [CrossRef]

17. Brewer, P.G.; Peltzer, E.T.; Walz, P.M.; Coward, E.K.; Stern, L.A.; Kirby, S.H. Deep-sea field test of the $\mathrm{CH}_{4}$ hydrate to $\mathrm{CO}_{2}$ hydrate spontaneous conversion hypothesis. Energy Fuels 2014, 28, 7061-7069. [CrossRef]

18. Ors, O.; Sinayuc, C. An experimental study on the $\mathrm{CO}_{2}-\mathrm{CH}_{4}$ swap process between gaseous $\mathrm{CO}_{2}$ and $\mathrm{CH}_{4}$ hydrate in porous media. J. Petrol. Sci. Eng. 2014, 119, 156-162. [CrossRef]

19. Li, X.S.; Yang, B.; Li, G.; Li, B.; Zhang, Y.; Chen, Z.Y. Experimental study on gas production from methane hydrate in porous media by huff and puff method in Pilot-Scale Hydrate Simulator. Fuel 2012, 94, 486-494. [CrossRef]

20. Li, B.; Li, G.; Li, X.S.; Chen, Z.Y.; Zhang, Y. The use of heat-assisted antigravity drainage method in the two horizontal wells in gas production from the Qilian Mountain permafrost hydrate deposits. J. Petrol. Sci. Eng. 2014, 120, 141-153. [CrossRef]

21. Li, B.; Li, X.S.; Li, G.; Chen, Z.Y. Evaluation of gas production from Qilian Mountain permafrost hydrate deposits in two-spot horizontal well system. Cold Reg. Sci. Technol. 2015, 109, 87-98. [CrossRef]

22. Li, G.; Moridis, G.J.; Zhang, K.N.; Li, X.S. Evaluation of gas production potential from marine gas hydrate deposits in Shenhu area of South China Sea. Energy Fuels 2010, 24, 6018-6033. [CrossRef]

23. Dana, E.; Skoczylas, F. Gas relative permeability and pore structure of sandstones. Int. J. Rock. Mech. Min. 1999, 36, 613-625. [CrossRef] 
24. Davy, C.A.; Skoczylas, F.; Lebon, P.; Dubois, T. Gas migration properties through a bentonite/argillite interface. Appl. Clay. Sci. 2009, 42, 639-648. [CrossRef]

25. Wang, Y.; Feng, J.C.; Li, X.S.; Zhang, Y.; Li, G. Large scale experimental evaluation to methane hydrate dissociation below quadruple point in sandy sediment. Appl. Energy 2016, 162, 372-381. [CrossRef]

26. Minagawa, H.; Ohmura, R.; Kamata, Y.; Ebinuma, T.; Narita, H.; Masuda, Y. Water permeability measurements of gas hydrate-bearing sediments. In Proceedings of the Fifth International Conference on Gas Hydrates, Trondheim, Norway, 13-16 June 2005.

27. Masuda, Y.; Naganawa, S.; Ando, S.; Sato, K. Numerical calculation of gas production performance from reservoirs containing natural gas hydrates. SPE J. 1997, 29, 201-210.

28. Konno, Y.; Yoneda, J.; Egawa, K.; Ito, T.; Jin, Y.; Kida, M. Permeability of sediment cores from methane hydrate deposit in the Eastern Nankai Trough. Mar. Petrol. Geol. 2015, 66, 487-495. [CrossRef]

29. Li, J.F.; Ye, J.L.; Qin, X.W.; Qiu, H.J.; Wu, N.Y.; Lu, H.L.; Xie, W.W.; Lu, J.A.; Peng, F.; Lu, C.; et al. The first offshore natural gas hydrate production test in South China Sea. China Geol. 2018, 1, 5-16. [CrossRef]

30. Liu, Z.F.; Colin, C.; Li, X.J.; Zhao, Y.L.; Tuo, S.T.; Chen, Z.; Siringan, F.P.; Liu, J.T.; Huang, C.Y.; You, C.F.; et al. Clay mineral distribution in surface sediments of the northeastern South China Sea and surrounding fluvial drainage basins: Source and transport. Mar. Geol. 2010, 277, 48-60. [CrossRef]

31. Liu, J.F.; Skoczylas, F.; Talandier, J. Gas permeability of a compacted bentonite-sand mixture: Coupled effects of water content, dry density, and confining pressure. Can. Geotech. J. 2015, 52, 1159-1167. [CrossRef]

32. Liu, J.F.; Song, Y.; Skoczylas, F.; Liu, J. Gas migration through water-saturated bentonite-sand mixtures, COx argillite, and their interfaces. Can. Geotech. J. 2016, 53, 60-71. [CrossRef]

33. Liu, J.F.; Skoczylas, F.; Liu, J. Experimental research on water retention and gas permeability of compacted bentonite/sand mixtures. Soils Found. 2014, 54, 1027-1038. [CrossRef]

34. Yang, S.X.; Liang, J.Q.; Lu, J.A.; Qu, C.W.; Liu, B. New understandings on the characteristics and controlling factors of gas hydrate reservoirs in the Shenhu area on the northern slope of the South China Sea. Front. Earth Sci. 2017, 24, 1-14.

35. Zhang, J.M.; Li, X.S.; Chen, Z.Y.; Li, Q.P.; Li, G.; Lv, T. Numerical simulation of the improved gas production from low permeability hydrate reservoirs by using an enlarged highly permeable well wall. J. Petrol. Sci. Eng. 2019, 183, 106404. [CrossRef]

36. Loosveldt, H.; Lafhaj, Z.; Skoczylas, F. Experimental study of gas and liquid permeability of a mortar. Cem. Concr. Res. 2002, 32, 1357-1363. [CrossRef]

37. Xu, P.; Yu, B.M. Developing a new form of permeability and Kozeny-Carman constant for homogeneous porous media by means of fractal geometry. Adv. Water Resour. 2008, 31, 74-81. [CrossRef]

38. Carman, P.C. Permeability of saturated sands, soils and clays. J. Agric. Sci. 1939, 29, 262-273. [CrossRef]

39. Carman, P.C. Fluid flow through granular beds. Chem. Eng. Res. Des. 1997, 75, S32-S48. [CrossRef]

40. Li, X.S.; Wang, Y.; Duan, L.P.; Li, G.; Zhang, Y.; Huang, N.S. Experimental investigation into methane hydrate production during three-dimensional thermal huff and puff. Appl. Energy 2012, 94, 48-57. [CrossRef]

41. van Genuchten, M.T. A closed-form equation for predicting the hydraulic conductivity of unsaturated soils. Soil Sci. Soc. Am. J. 1980, 44, 892-898. [CrossRef]

(C) 2019 by the authors. Licensee MDPI, Basel, Switzerland. This article is an open access article distributed under the terms and conditions of the Creative Commons Attribution (CC BY) license (http://creativecommons.org/licenses/by/4.0/). 